\title{
LiBERALISM AND BEYOND: TOWARD A Public Philosophy of EducAtion
}

\section{Maxine Greene}

The educational philosophers who wrote in The Social Frontier dealt unabashedly with problems arising out of the social conflicts of their time. Their universe of discourse opened outward to the turbulent domains of politics, economics, and the ideational changes occurring all-around. Fundamental to their concern was the question of liberty in its relation to equality and social control. Rejecting 18 th century atomistic notions, persistent dualisms, and the association of liberalism with laissez-faire ideas, they sought a view that "combined equality and liberty as coordinate ideals ..."1 Because this placed them in a position of opposition to what they called "finance-capitalism," they then had to confront the problem of how socioeconomic structures could be changed without violent revolution and the loss of freedom. Unless those structures were changed, many of them believed, democratic education would be inconceivable. And democratic education, focused on the development of critical thinking and the release of human power for choice and action, was necessary if democracy itself was to be preserved.

For them, the "bewitchment of thought" that endangered democracy was not due mainly to conceptual or linguistic confusions. They attributed it largely to the perpetuation of old pieties, outmoded "individualist" views of American society. The lags, the fixities of thought, were functions of a deficient status quo; they prevented people from redefining social goals. Centering their attention on the demands of an "age of collectivism," the contributors to the Frontier showed no particular interest in what existentialists called the "human condition," nor in "Being," nor in the life of consciousness. They inhabited a world in which human intelligence, open communication, and cooperative action presumably could be counted upon to solve the major problems facing humankind. Differ though they might on political and social issues (the relevance of Marxism, the significance of class interest in America, the meanings of social reconstruction), they shared a range of fundamental commitments, many having to do with educational philosophy. Philosophy, as they viewed it, was not only the "theory of education;"3 its function was to direct educational practice and to shape its purposes. Since education was primarily a social enterprise of the moment for the future of society, 
educational philosophy's basic concerns could not but be social and political. Indeed, its aims ought to be identical with those of democracy.

Dewey, Childs, Kilpatrick, Brameld, Rugg, Bode, Counts, and the others were writing in a period of economic depression and transition, and in an atmosphere of precarious reforms. They were writing, too, at a time of fascist expansion and aggression abroad, culminating in the Second World War. The journal did not last long enough for them to have to come publicly to terms with the bombing of Hiroshima and the threat of nuclear obliteration. Although they knew about the existence of the German concentration camps, they appeared not to be familiar with the Nazis' invention of a "Final Solution," the scientifically planned and executed extermination of millions of Jews. There was an occasional noting of signs in the wind with regard to the misuse of industrial power; but most contributors did not anticipate the consequences of science's new links to technical undertakings (as at Los Alamos) nor to large-scale industrial production. Still optimistic about the scientific method and attitude and what they could achieve, they did not predict the domination by depersonalized technology of almost every area of social life; nor did they imagine the phenomenon of what Jacques Ellul was to call "self-augmenting technique." There is little evidence that they confronted the influence of positivistic thinking and the split between empirical and moral considerations such thinking entailed. Moreover, although there were occasional comments about thought control by means of media, they were in no position to predict the effect television and radio would have on thinking as well as discourse; they could not have conceived what has been described as the "industrialization of the mind." Perhaps most important, they did not (Dewey aside) see the overwhelming of a potentially "articulate public"' by a mass of "job-holders and consumers,"7 including the members of trade unions on who so many rested their hopes. Although, in the first issue, Kilpatrick drew attention to the emergence of "a highly complex urban and industrial order" marked by "a common dependence on a far-flung productive and distributive mechanism," the contributors did not appear to see the advent of a bureaucratized, overly "administered" society, in which the individualism they lamented would be replaced by large-scale corporate planning and control.

Events of such magnitude could not but transform the ground on which people attempted to "do" educational philosophy; and it is difficult to believe that, as the new realities entered consciousness, educational philosophers became less and less interested in the relation between education and the culture at large. In part, it was a response to often contemptuous criticism by the conservative scholarly community; in part, it was a desire to "profession alize" and make more rigorous aspects of what was called "educational foundations." In any case, many members of the post-war generation of educational philosophers had been trained in academic philosophy; and academic philosophy, 
in their time, was being affected and often remade by the influence of British analytic philosophy. The wide-ranging "polity" addressed by American thinkers from Emerson to Dewey was gradually replaced by a version of what the British thought of as a rational community, mainly composed of university graduates (almost always men).

Philosophical systems were questioned; so were efforts to draw implications for practice from a variety of philosophical "movements." With the major focus on clarification and criticism of terminology, arguments, "slogans," on what Israel Scheffler was to call "the language of education," " philosophers refused to speak of themselves as guides to classroom practice. Such discussions as D. J. O'Connor's, differentiating the use of "theory" in the natural sciences from the use of the same term with regard to education, ${ }^{9}$ seemed to invalidate the treatment of philosophy as "theory of education." In time, such thinkers as R. S. Peters, sharply distinguishing the concept of "education" from "schooling," ${ }^{10}$ made it suspect to speak of education as a way of bringing about social reforms. (Dewey, of course, had earlier made the distinction between education and schooling; ${ }^{11}$ but, for him, "education" was a larger and more encompassing concept. It referred to the multiple efforts to transmit knowledge and values throughout the culture, not in the specialized atmosphere of the school alone.) Analytic philosophers, also, were continually reminded of the Humean insistence on the autonomy of the sphere of values; and fewer and fewer were inclined to draw conclusions about what "ought" to be from descriptions of what "was" in the social domain. As for the relatively few who ventured into modern Continental philosophy: the tendency was to focus on the individual's quest for freedom, authenticity, and meaning, rather than on broader struggles for social change.

But, even as educational philosophers were divorcing themselves from the problems of public schools, a serious erosion of faith in those schools had already begun. The climate for it was created by right-wing attacks on their "mediocrity" and distorted images of "progressivism" that filled the public prints. The reports of near-illiteracy among draftees in the Second World War added to the disillusionment; and there was little surprise when, at the time of the Sputnik panic, a group of academic scholars assumed responsibility for curriculum reform. The perceived role of the school as an agent of social reconstruction was arbitrarily replaced by the view that the school's prime function was to contribute to national security and the surpassing of the USSR in scientific and engineering expertise. Cognitive "excellence" became the watchword; the promotion of individual talent, the overriding goal.

In the Sixties, with the election of Lyndon B. Johnson to the Presidency, there seemed (for a moment) to be a resurgence of the Frontier's hopes and ideals. Responding, in part, to the Civil Rights movement and the sudden visibility of the "invisible poor," the reforms and remedies made possible by the Elementary and Secondary Education Act were proposed as modes of "equalizing," "compensating," instituting overdue social change. In certain respects, 


\section{M. GREENE}

all this represented an expression of the "liberalism" John Dewey and his colleagues had in mind. The failures, the cut-offs that followed after were due, in part, to the heavy investment in the Vietnamese War; but they were also testimony (as the Reverend Martin Luther King and others made clear) to the fact, made very explicit by The Social Frontier, that socioeconomic structures had themselves to be changed if liberalism was to be achieved.

The contributors to the Frontier, it must be said, ventured occasionally into discussions of civil liberties, but said little or nothing about the racial problem in America or how it related to the work of public schools. There was mention of "the Negro" on occasion, of discrimination and exclusion, of the need on the part of the "Negro" to call his plight to the attention of the public. (No mention was made of what is now called the "gender gap" and the discrimination against women that constituted another threat to equity.) In any case, the Frontier writers neither saw the treatment of excluded groups as the test of democratic education's claims; nor did they anticipate the ways in which efforts to achieve equity would further erode confidence in what education could achieve. Segregation and discriminatory practices were offensive enough. As serious was the sudden recognition that school reforms, even when properly subsidized, were not themselves going to insure thoroughgoing equality or repair the damage done by decades of exploitation and exclusion. Again, major structural transformations were needed; and no polity existed (nor political party, nor nationwide movement) ready to bring them about. Along with the anger and disillusionment felt by the reformers and the defenders of civil rights, there was a spurt of latent resentment in the face of regulations aimed at effecting school integration and improvement. Racism and self-interest became manifest everywhere as busing arrangements were legislated, open enrollment programs, affirmative action, and the like. The tension between a demand for equality and the affirmation of personal liberty took on new forms as thousands of white parents objected to federal requirements that seemed to cancel out their right to self-determination. What followed, among such groups, were well-publicized rejections of public education. "Free" white schools were established, to be followed by "Christian" or "fundamentalist" schools set up by people intent on protecting their parochial interests against the incursions of integration and (later) "secular humanism."

In the period of school reform and its slow disintegration, "romantic" and "revisionist" critiques of the public school began to appear. The Frontier writers had dealt with threats to the school by conservatives, business interests, and such groups as the American Legion. They had dealt often enough with the difficulties involved in educating for growth and free expression in a materialist, capitalist society. But they never regarded the schools as intentionally repressive and selective, no matter how responsive they sometimes became to restrictive outside forces. The "romantics" saw. the imposition of worn-out middle-class values when they looked at the schools; they saw. teachers threatened by the "natural". capacities and energies of children; 
they saw people being socialized into respectability and small-mindedness, deprived of significant life goals. Certain ones, libertarian and anarchist in point of view, provided new legitimations for "free" or private education (or for "de-schooling"). They objected to any kind of centralized planning and associated liberalism with "sorting" and state control. Social reconstruction, in the Frontier sense, meant nothing to them; more Emersonian than Deweyan, they thought changes would be brought about through regeneration of the Single One.

The radical "revisionists," in their turn, came somewhat closer to the more radical Frontier thinkers; but they tended to apply the tools of Marxism in a different way and within a different frame. They saw the schools as deliberately stratifying the young in accord with the demands of industrial capitalism. The very structures of educational institutions, they said, were-and were meant to be-manipulative. Testing procedures, tracking devices, curriculum emphases: all were intended to keep workers' children, immigrants, and minorities in their place; socio-economic hierarchies were defended and maintained. Liberalism, for them, was to be identified with capitalism; the only hope was in the teaching of socialist values within the schools, in some effort to found revolutionary-or reconstructive-communities.

Legitimate philosophic problems were clearly implicit in the various modes of critique; but there was little response from the field of educational philosophy. Shifts and changes in academic philosophy were required before the focus widened in any degree at all. Attention was still concentrated on concept analysis, ordinary language, speech-act theory, the logic of arguments, the "language of morals." Here and there, a few educational philosophers did concept analysis with respect to "equality" or "authority;"12 but little serious attempt was made to relate what was happening in schools (or what might happen) to desired changes in the culture at large. When Thomas Kuhn's The Structure of Scientific Revolutions ${ }^{13}$ appeared, there was some effort to look at the field of educational philosophy through Kuhn's constructs of paradigms and anomalies, and a certain restlessness moved some to wider spheres. When John Rawls's Theory of Justice ${ }^{14}$ appeared with its rigorous examination of "the prime virtue of the polity," educational philosophers began more frequently to apply their analytic skills in the social and political domains. The rising interest in moral reasoning and moral development enlisted a number of them, usually in the analytic-occasionally in the Deweyan-mode.

More consequential for a return to the concern and spirit of The Social Frontier were ideas stemming largely from the fields of sociology, Continental philosophy, and curriculum theory. The idea of "constructed" social reality, developed by Alfred Schutz $\mathrm{z}^{15}$ and expanded upon by Peter Berger and Thomas Luck-Schultzmann, ${ }^{16}$ occasioned new interest in what Jonas Soltis now calls "sociocentric" approaches to knowledge, ${ }^{17}$ certain strands of which connect to Dewey's epistemology.

By now, however, the social and sociocentric concerns being registered in educational philosophy have also been affected by social phenomenology, the work 
of certain radical sociologists, ${ }^{18}$ and the critical theory developed by the Frankfurt School. ${ }^{19}$ An exemplary instance of a thinker grounded in phenomenology and Marxism, and at once to praxis, is Paulo Friere, ${ }^{20}$ who is influencing the thinking of many educators concerned with social transformation. Among these are such curriculum theorists and sociologists as Michael Apple ${ }^{21}$ and Henry Giroux, ${ }^{22}$ neither of whom has been fully accepted by educational philosophers, old Marxists, or by the Brameldians who compose the Society for Educational Reconstruction. Even so, they have drawn variously and productively from the resources of European political philosophy and used these to anatomize the school in its relation to society. They have shed light on the school's role in "cultural reproduction," on the unequal distribution of knowledge, and on the perpetuation of "hegemony." In their search for the shapes of possible "resistance," however, they have said almost nothing about the reemergence of a public in the United States and nothing about the importance of recapturing the realm of discourse Sheldon Wolin says has been taken over by the country's conservatives. ${ }^{23}$ Most recently, and perhaps most relevantly, Walter Feinberg has undertaken a philosophical inquiry into the various dimensions of social reproduction, including an examination of the preconceptions of many recent scholars who have understood education differently: analytic philosophers, interpretive and Marxist critics, revisionist historians. ${ }^{24}$ Significantly, he concludes with what constitutes an introduction to "education and the self-formation of the public," which he believes might occur under conditions of dialogue and "unmanipulated judgment." Socially oriented and committed though he appears to be, he has not dealt with the problematic of liberalism nor with what a public philosophy of education might turn out to be.

Educational philosophers now live and work at a moment when, as Dewey put it in The Social Frontier, ${ }^{25}$ the "letter" is destroying the "spirit" of liberalism. What he said about the "meaning of liberalism" at that time might well be said today. He was concerned about the anti-social interests of the dominant social class and about its uses of the dogma of laissez-faire individualism to justify a "hands-off" policy by government. What began, he wrote, "as a movement in the direction of greater liberty for expression of the energies of man and which was put forward as giving every individual new opportunities and new powers, has become socially oppressive for the greater number of individuals. It has almost resulted in identifying the power and liberty of the individual with ability to achieve economic success ...." He concluded that a "new liberalism" required radical changes in economic institutions and political arrangements so that "social control of forces and agencies socially created may accrue to the liberation of all individuals associated together in the great undertaking of building a life that expresses and promotes human liberty." Words like these in their passion are in many ways expressive of the commitment of The Social Frontier: a commitment to liberate and to transform. But, we must add, in the world the contributors knew. 
For all the relationships and the live implications, educational theorists today are likely to constitute their social realities quite differently. They look out on a world of broken promises and destroyed faiths, a world where tortures continue to be the order of the day in both hemispheres, where totalitarian thought controls multiply, where wars go on eternally, where multinational corporations extend their influence further and further, where the prospect of world government recedes each day. The vision of human societies becoming responsive to intelligence and moderation dims accordingly. Even the so-called "democracies" tolerate-and sometimes sponsor-brutalities and violence toward human beings. And no one can claim economic or commercial success; since economic failures seem unmanageable, no matter what the system. Centralized planning seems unworkable; the scale and cost of support networks make localism seem unthinkable. Wherever one looks, facts like these are obscured. The "space" of human association is dominated by propaganda, the artificial languages of "cost-benefit" concerns, or simple mystification. It becomes increasingly difficult for individuals to express or to communicate their own particular values, values formed-not as members of a "crowd" or an "audience" or a "congregation"- but as ordinary beings trying to learn how to live together, how to "be." In the background, sometimes confronted and sometimes denied, there is the ever present danger of nuclear holocaust, the possibility of losing what human beings have in common: their world, their human world.

In the meantime, in our country, federal demands for educational "excellence" are openly linked to "national interest," meaning economic and military primacy. Stress is laid on "effectiveness," on scientific proficiency, on computer literacy. Efforts are deliberately made to exclude value education from the schools, as cognitive expertise in the fields relevant to expanding technology becomes the overriding norm. And the grassroots population, suffering unemployment, dislocation, and anxieties related to the "high tech" society they are told is in the making, can only call for more and more concentration on technical skills, "competencies," saleable aptitudes. Disturbing numbers of them, black and white, react to talk of "tax credits" with plans to send their children to private or parochial schools.

This is but one of many indications of the contemporary "eclipse of the public," ${ }^{26}$ of a feeling that the space between separate individuals is empty, a kind of void. Somehow that space must be recreated; somehow, we must bring into existence an "in-between."27 To move toward a public philosophy of education in days like these is to work toward what was once called theoria, meaning a normative conception of a rational and humane society. It is not a matter of sociological description or the kind of explanatory enterprise associated with political science. Nevertheless, the effort ought to incorporate some of the "experimental" consciousness of The Social Frontier, avoiding doctrine and final answers, keeping the goal in the realm of possibility. And, certainly, the questions must be kept open: the questions about liberty, equality, planning, social 
reconstruction, social control. If education has to do with empowering persons for participant and articulate membership in their society, these issues have as much to do with education as they do with the surrounding culture. Although we (like Dewey and others) cannot claim that schools have the capacity to "change the social order," we can affirm a continuity between the public space we would like to see and what happens (or ought to happen) in public schools.

In pondering what a public philosophy of education might be today, however, we are not required to go back in time in order to recover what some believe is lost. The optimistic humanism, the "social consciousness" of the Frontier contributors are appealing enough to make certain readers want to set aside what has been learned about language and consciousness, about the problematic of empiricism, about technology and hegemony, and even about the insoluble nature of some of the problems now facing the world. But there is no turning back. There is no undoing of the extermination camps or the Gulags, of the recognition that educated and intelligent people can commit unimaginable crimes. There is no undoing of Hiroshima and Nagasaki, no denying of our country's responsibility for massacres. Nor can there be a covering over of the assassinations in the recent past, of the extremities in Vietnam and Cambodia, of the "lying in public" that has marked our several administrations, of the moralistic masking of the truth.

Similarly, there can be no rejection of what we have learned in educational philosophy itself, when it comes to clarification and critical understanding. There will remain differences between those who take the analytic, highly rationalist, often Kantian approach and those who insist on the importance of standpoint, perspective, and the intentionality of consciousness. But there may be widening areas of agreement on the matter of constructed or constituted realities, on the need for "communicative competence" 28 and new modes of "critico-creative thinking"29 And, surely, when it comes to the matter of human reality, there is no denying today that people become "human" by means of communication and within matrices of relationship. Whether personhood is understood in the sense of centers of consciousness ${ }^{30}$ or in the sense of what has to be chosen, what is not yet, ${ }^{31}$ there is at least some tacit acknowledgment that to be an individual depends upon being with others in a way that entails mutuality and regard. It is unlikely, therefore, that the old "either/ors" (liberty or social control); equality or self-determination; selfactualization or socialization) would today provoke serious philosophical debate.

As for the crucial issues of values and ethics, there remains a spectrum of points of view. Like the academic philosopher today, however, the educational philosopher tends to look outward from his/her study or institution. What is specifically "desirable" in educational activity still concerns him/her; so does the ubiquitous question of the "worthwhile." The matter of "oughtness," the matter of "norm-governed action" in the course of learning, the matter of virtue: all these still preoccupy the educational philosopher. However, even as philosophy in other 
fields has become concerned with issues of justice, human rights, and social welfare, so has educational philosophy begun to consider related questions as they touch upon teaching and learning, and upon the structures of the schools.

Once a philosopher chooses to enter into the great "conversation" 32 about freedom, equity, human rights, power, and choice, that philosopher has to some extent "gone public." There remains, however, the contribution to be made to recreation of a public space, to the reemergence of an "articulate public" by those whose primary focus is on the public school. For Sheldon Wolin, ${ }^{33}$ the domination of public discourse by economics with its special language of "cost-benefit" and "rationality" makes difficult, if not impossible, the existence of a civic ethic. The reason for a civic culture, he writes, "is that citizens will have to cooperate, tell the truth, respect each other's rights and sensibilities, observe the law, and pay taxes, if a self-governing and free society is to be possible." ${ }^{34} \mathrm{~A}$ public philosophy is needed to nurture such an ethic; but, when such a philosophy is grounded in economics, the ethic is declaredobsolete. Much in the spirit of The Social Frontier, Wolin views the anti-political power now being usurped as "generated by the search for private advantage;" there exists no principle for finding common ground. He finds conservative groups, with arguments grounded in the political culture of a time long past, taking over the space where significant human values are discussed. The Moral Majority, the anti-abortionists, the creationists, the fundamentalists: these have, he says, in their solidarity and sense of community, provided a substitute for politics. Doing that, "they leave the entire structure of power, inequality, hopelessness, and growing repression wholly untouched."

Whether Wolin's sense of despair is justified or not, whether a new public philosophy will "need the backing of the moral and religious conservatives" or not, he is surely correct in pointing to the impacts of the new economic positivism, especially as it becomes incorporated in official language and media explanations. The educational philosopher, still concerned about the nurture of intelligence and critical thinking, may well begin to "do" a more public philosophy if he/she attends-and empowers others to attend-to the nature of contemporary mystification and domestication. This not only means an understanding of how language is used and how it affects human consciousness; it means a deliberate effort to break through the impersonality and namelessness of speakers, the presumed "objectivity" that allows them to give their explanations the inexorability of natural law.

It means as well a conscious attentiveness to the actualities of lived experience in the classroom, to the common-sense realities in which sense-making begins. Biographies should be taken into account, and background awareness, so that students can be made conscious of the fact that "reality" signifies interpreted experience, and that interpretation is affected by location and by point of view. Schoollearning, "liberal education," even "initiation" mean empowering persons to interpret in more and more varied and complex ways, to structure their experiences with 
the aid of patterns made available by their "predecessors and contemporaries." 35 To know this, to recognize that understanding is a free act, undertaken by a person as center of consciousness, is to be somewhat defended against false consciousness. To be afflicted with false consciousness is to incorporate, without question, the artificial needs fabricated by advertising, to acquiesce in "commodity fetishism," ${ }^{36}$ to become the object of (rather than the listener to or the beholder of) popular culture.

To empower persons in this way may be to make it possible for them to come together, as distinctive beings, in "speech and action," ${ }^{37}$ in a space where freedom can once again come to be. To speak is to articulate and, at once, to discover what one thinks and how one sees. If situations can be created in which people are free to speak in "agent-revealing ways," as who and not what they are (as Hannah Arendt puts it), ${ }^{38}$ they may be able to bring into existence an "in-between," something more significant than a sharing of interest, something that creates a "web of relationships." It is this that makes possible the institution of a public space, brought into existence by people in their distinctiveness and in their moral equality. Given the opportunity to speak from their own perspectives about what lies between, what they hold fundamentally in common, they may be able to recreate a civic culture, a "common world."

If liberalism connotes (as some of the Frontier writers believed) a commitment to human liberation-liberation for action and speech and choice, the spirit of liberalism may be given play again if a public philosophy of education develops a theoria oriented to a public space. Again, there is no turning back. There is the need to clarify what it signifies to engage in critique, to pursue freedom, to be with others. And, in the tradition of The Social Frontier, to act in concert with others taking part in the ongoing conversation, to live toward. open possibility.

\section{Notes}

1. John Dewey, "Liberalism and Equality," Social Frontier II, no. 4 (January, 1936): 105.

2. Ludwig Wittgenstein, "The Blue Book," Philosophy in the Twentieth Century, Vol. II, ed. William Barrett and Henry D. Aiken (New York: Random House, 1962), 715.

3. John Dewey, Experience and Education (New York: Collier Books, 1963), 22.

4. Jacques Ellul, The Technological Society (New York: Vintage Rooks, 1967), 80.

5. R. N. Enzensberger, "The industrialization of mind," in The Consciousness Industry (New York: Seabury Press, 1974), 315.

6. John Dewey, The Public and Its Problems (Chicago: The Swallow Press, 1954), 184.

7. Hannah Arendt, The Human Condition (Chicago: University of Chicago Press, 1958), 43-45.

8. Israel Scheffler, The Language of Education (Springfield, IL: Charles C. Thomas, 1960).

9. D. J. O'Connor, An Introduction to the Philosophy of Education (New York: Philosophical Library 1957).

10. R. S. Peters, Ethics and Education (London: George Allen \& Unwin, 1978), chapter 1.

11. John Dewey, Democracy and Education (New York: The. Macmillan Company, 1916).

12. Peters, Ethics and Education, 237-65; R. S. Peters, Authority, Responsibility and Education (London: George Allen \& Unwin, 1959). 
13. Thomas S. Kuhn, The Structure of Scientific Revolutions (Chicago: University of Chicago Press, 1962; 1970).

14. John Rawls, A Theory of Justice (Cambridge: Harvard University Press, 1971).

15. Alfred Schutz, Collected Papers I: The Problem of Social Reality (The Hague: Martinus Nijhoff, 1967).

16. Peter L. Berger and Thomas Luckmann, The Social Construction of Reality (Garden City: Anchor Books 1967).

17. Jonas F. Soltis, "Education and the Concept of Knowledge," in Philosophy and Education, ed. J. F. Soltis (Chicago: Chicago University Press, 1981), 97-98.

18. See, e.g., Paul Connerton, ed., Critical Sociology (New York: Penguin Books, 1978) and John Rex, Sociology and the Demystification of the Modern World (London: Routledge and Kegan Paul, 1974).

19. See, e.g., Andrew Arata and Eike Gebhardt, eds., The Essential Frankfurt Reader (New York: Urizen Books, 1978).

20. Paulo Freire, Pedagogy of the Oppressed (New York: Herder and Herder 1970).

21. Michael W. Apple, Ideology and Curriculum (Boston: Routledge and Kegan Paul, 1979).

22. Henry Giroux, Ideology, Culture and the Process-Schooling (Philadelphia: Temple University Press, 981).

23. Sheldon S. Wolin, “The New Public Philosophy," Democracy (October 1981): 23-36.

24. See, e.g., Clarence J. Karier, Shaping the American Educational State: 1900 to the Present (New York: The Free Press, 1975) and Michael B. Katz, The Irony of Early School Reform (Cambridge: Cambridge University Press; 1968).

25. John Dewey, “The Meaning of Liberalism," Social Frontier II, no. 3 (December, 1945): 74-75.

26. Dewey, The Public and Its Problems, 110-42.

27. Arendt, The Human Condition, 182-83.

28. Jurgen Habermas, Communication and the Evolution of Society (Boston: Beacon Press, 1979), 26-68.

29. John Passmore, "On teaching to be critical," in The Concept of Education, ed. R. S. Peters (New York: The Humanities Press, 1967), 200-201.

30. See Peters, Ethics and Education, 211.

31. See Jean-Paul Sartre, The Transcendence of the Ego (New York: The Noonday Press, 1936).

32. Michael Oakeshott, "The Voice of Poetry in the Conversation of Mankind," Rationalism and Politics (London: Methuen Press, 1962).

33. Wolin, "The New Public Philosophy," 23.

34. Ibid., 33.

35. Schutz, Collected Papers I: The Problem of Social Reality, 10.

36. See "The Social System of Capitalism," in Karl Marx: Selected Writings in Sociology and Social Philosophy, eds. T. R. Battomore and Maximilien Rubel (New York: McGrawHill Paperbacks, 1964), 146-60; Andrew Arata, "Esthetic Theory and Cultural Criticism," in The Essential Frankfurt School Reader (New York: Urizen Books, 1978), 190.

37. Arendt, 181-83.

38. Ibid., 182.

Maxine Greene was the William F. Russell Professor Emerita in the Foundations of Education at Teachers College, Columbia University. 
